JURNAL ILMIAH MANAJEMEN BISNIS DAN INOVASI UNIVERSITAS SAM RATULANGI (JMBI UNSRAT)

\title{
MENGUJI STRATEGI DESA WISATA \\ DALAM MEMBANGUN KEUNGGULAN BERSAING DI ERA REVOLUSI INDUSTRI 4.0
}

\section{Gede Deddy Rahmat}

Universitas Pendidikan Nasional Denpasar

A R T I C L E I N F O

Keywords: Strategies, Role of Tourism Village Government, Digitalization, Tourism Village
Kata kunci: Strategi, Peran Pemerintah Desa Wisata, Digitalisasi, Desa Wisata

Corresponding author:

I Gede Deddy Rahmat dededdyrahmat@gmail.com
Abstract: This research aims to determine and test the effectiveness of the role of the village government in creating a Tourism Village strategy to build competitive advantage in the Era of Industry Revolution 4.0 and to find out the factors that hinder and influence the role of the village government in managing the village of Blimbingsari Tourism Village which is a Special Interest Tourism Village (Spiritual). This research used descriptive qualitative method. The informants in this research were the Headman of Blimbingsari, Village Secretary, BUMDes Treasurer, Secretary of the Tourism Committee, Homestay Owners, Village Community Leaders and Academics. The technique of data collection is done by using triangulation technique (combined), the results of qualitative research emphasize the quality of the meaning of good research.

The research results obtained by researchers from interviews, observations, and documentation are the role of the Blimbingsari Tourism Village Government to be carried out well. The Blimbingsari Tourism Village Government has a good role as a stabilizer, innovator and motivator. The provision of internet infrastructure and human resource development is a factor in the development of Blimbingsari tourism village in building competitiveness in the era Industry Revolution 4.0.

Abstrak: Penelitian ini bertujuan untuk mengetahui dan menguji efektifitas peran pemerintah desa dalam menciptakan strategi Desa Wisata untuk membangun keunggulan bersaing di Era Revolusi Industri 4.0 serta mengetahui faktor-faktor yang menghambat dan mempengaruhi peran pemerintah desa dalam pengelolaan desa Desa Wisata Blimbingsari yang merupakan Desa Wisata Minat Khusus (Rohani). Penelitian ini menggunakan metode deskriptif kualitatif. Informan dalam penelitian ini yaitu Perbekel Desa Blimbingsari, Sekretaris Desa, Bendahahara BUMDes, Sekretaris Komite Pariwisata, Pemilik Homestay, Tokoh Masyarakat Desa dan Akademisi. Teknik pengumpulan data dilakukan dengan teknik triangulasi (gabungan), hasil penelitian kualitatif lebih menekankan pada kualitas makna penelitian yang baik.

Hasil penelitian yang didapat peneliti dari wawancara, observasi, dan dokumentasi adalah peran Pemerintah Desa Wisata Blimbingsari dilakukan dengan baik. Pemerintah Desa Wisata Blimbingsari memiliki peran yang baik sebagai stabilitator, innovator dan motivator. Pengadaan infrastuktur internet dan pengembangan sumber daya manusia menjadi faktor pada pengembangan desa wisata Blimbingsari dalam membangun daya saing di era Revolusi Industri 4.0. 


\section{PENDAHULUAN}

Bali sangat dikagumi di seluruh dunia karena pariwisata budayanya. Bali beberapa kali terpilih sebagai destinasi terbaik versi majalah terkenal Singapore Magazine sejak tahun 2010. Pariwisata Bali berkembang pesat dengan keunikannya bahkan Bali dijuluki sebagai the island of God. Dalam UndangUndang Nomor 10 tahun 2009 tentang kepariwisataan disebutkan bahwa penyelenggaraan kepariwisataan ditujukan untuk meningkatkan pendapatan nasional dalam rangka meningkatkan kesejahteraan dan kemakmuran rakyat, memperluas dan memeratakan kesempatan berusaha dan lapangan kerja, mendorong pembangunan daerah, memperkenalkan dan mendayagunakan obyek dan daya tarik wisata di Indonesia serta memupuk rasa cinta tanah air dan mempererat persahabatan antar bangsa. Perkembangan industri tersebut tidak hanya berdampak pada peningkatan penerimaan devisa negara, namun juga telah mampu memperluas kesempatan berusaha dan menciptakan lapangan pekerjaan baru bagi masyarakat dalam mengatasi pengangguran di daerah (Rahma, 2013).

Dalam Peraturan Daerah Propinsi Bali, Nomor 2 tahun 2012 tentang Kepariwisataan Budaya Bali disebutkan kepariwisataan adalah keseluruhan kegiatan yang terkait dengan pariwisata dan bersifat multidimensi serta multidisiplin yang muncul sebagai wujud kebutuhan setiap orang dan negara serta interaksi antara wisatawan dan masyarakat setempat, sesama wisatawan, pemerintah pusat, pemerintah daerah dan pengusaha. Manfaat industri pariwisata terutama dirasakan oleh para pemangku kepentingan (stakeholders), diantaranya pemerintah, pemerintah daerah, dunia usaha, dan masyarakat (baik sebagai wisatawan maupun sebagai tuan rumah), sehingga masing-masing pihak tersebut memiliki peran dalam menjalankan industri pariwisata (Ismayanti, 2010).

Berdasarkan pendataan Potensi Desa (Podes) 2018, Membangun Indonesia dari Pinggiran Melalui Pendataan Potensi Desa (Podes) 2018 No. 06/01/51 Th. II, 2 Januari 2019 dari Badan Pusat Statistik Provinsi Bali yang mengumpulkan informasi terkait potensi wisata di desa/kelurahan. Pengembangan wisata di desa/kelurahan dapat menjadi sumber perekonomian baru dengan tetap memegang teguh warisan budaya. Desa/kelurahan wisata menurut Pendataan Podes 2018 adalah sebuah kawasan perdesaan yang memiliki beberapa karakteristik khusus untuk menjadi daerah tujuan wisata. Keberadaan desa wisata diatur/ditetapkan dalam peraturan daerah (Perda) setempat. Pada umumnya, penduduk di kawasan desa wisata memiliki tradisi dan budaya yang khas, serta alam lingkungan yang masih terjaga. Pendataan Podes 2018 mencatat bahwa ada 110 desa wisata dan 162 desa dengan objek wisata di Provinsi Bali.

Di Era Digital atau yang lebih sering disebut dengan era revolusi industri 4.0, harus dimanfaatkan oleh semua industri, terlebih industri pariwisata, termasuk diantaranya desa wisata. Salah satunya yaitu cara mempromosikan desa wisata secara digital, diharapkan semakin banyak yang mengetahui potensi desa wisata, bisa bersaing untuk memperebutkan pasar, mendatangkan pengunjung serta membuat pengunjung menjadi loyal dengan destinasi yang dimiliki desa wisata.

Pengelola atau pemerintahan desa harus berpikir "Out of The Box" untuk bisa menciptakan strategi bersaing dalam membangun keunggulan bersaing, bersyukur desa wisata yang memiliki dan dianugerahi keindahan alam luar biasa yang hanya tinggal mengemas daerahnya menjadi objek destinasi kunjungan, bagi desa yang tidak mempunyai keindahan alam harus bisa menyajikan kegiatan wisata "Kekinian" agar bisa menarik kunjungan wisatawan. Untuk itulah diperlukan peran pemerintah desa dalam menentukan strategi yang tepat dalam membangun keunggulan bersaing dalam industri ini, strategi dan inovasi-inovasi terutama dalam bidang teknologi informasi sangat diperlukan untuk bisa bersaing dalam industri ini.

Dalam menentukan strategi desa wisata untuk membangun keunggulan bersaing tentu peran dari pemerintah desa sangatlah penting, penelitian sebelumnya yang berkaitan dengan penelitian ini yakni, menurut penelitian Larasati dan Kurrahman (2019) menyatakan bahwa faktor-faktor yang mempengaruhi 
pelaksanaan peran pemerintah desa dalam pengelolaan wisata hutan pinus adalah keadaan alamnya yang terpengaruh saat musim hujan dan keadaan sumber daya manusianya yaitu kurangnya kesadaran dan kemampuan masyarakat terhadap pengelolaan Wisata Hutan Pinus. Sehingga perlu adanya pelatihan dan pendampingan secara intensif dari Pemerintah Desa Bendosari. Demikian juga dengan penelitian yang dilakukan oleh Sari, Sintiya Marcela (2017) membahas tentang peran yang dilakukan oleh pemerintah daerah Kota Kediri, melalui Dinas Koperasi dan Usaha Mikro Kecil dan Menengah Kota Kediri untuk meningkatkan keunggulan kompetitif kerajinan tenun ikat bandar kidul melalui, peningkatan kemampuan finansial, pengembangan pemasaran, pengembangan Sumber daya Manusia, dan peningkatan kemudahan dalam pelayanan perijinan, penguatan kelembagaan melalui pengembangan usaha.

Dari penelitian-penelitian tersebut, terdapat kesamaan dimana diperlukan peran pemerintah desa dalam pengembangan sumber daya manusia baik untuk mengembangkan desa wisata hutan pinus maupun untuk mengembangkan UMKM.

Belum ada penelitian yang meneliti peran pemerintah desa wisata secara spesifik yaitu mengenai strategi dan peran pemerintah desa wisata minat khusus dalam hal ini desa wisata rohani dalam membangun keunggulan bersaing di era revolusi industri 4.0. Oleh karena itu penulis tertarik untuk melakukan penelitian dimana dalam penelitian ini penulis ingin mendalami, mengetahui dan menguji efektifitas tentang peran pemerintah desa wisata minat khusus (rohani) dalam membangun keunggulan bersaing terutama di Era Revolusi Industri 4.0.

\section{Teori Peran}

\section{TINJAUAN PUSTAKA}

Teori peran (role theory) merupakan perpaduan antara disiplin ilmu psikologi, sosiologi, dan antropologi. Ketiga bidang ilmu tersebut mengambil istilah peran dari dunia teater. Pada pementasan teater, seorang aktor harus berperan sebagai tokoh tertentu. Ketika menjalankan perannya tokoh tersebut diharapkan berperilaku secara tertentu (Sarwono, 2015 : 215). Setiap peran yang diberikan telah memiliki sebuah identitas yang membedakan masing-masing individu mengenai siapa dan bagaimana individu bertindak dalam situasi tertentu.

Ditinjau dari Literatur Perilaku Organisasi, peran ini merupakan salah satu komponen dari sistem sosial organisasi, selain norma dan budaya organisasi. Di sini secara umum 'peran' dapat didefinisikan sebagai "expectations about appropriate behavior in a job position (leader, subordinate)". Sebuah lingkungan organisasi dapat memengaruhi harapan setiap individu mensegani perilaku seseorang dalam menjalankan peran. Harapan akan peran tersebut dapat berasal dari peran itu sendiri, individu yang mengendalikan peran tersebut, masyarakat, atau pihak lain yang berkepentingan terhadap peran tersebut (Hutami \& Chariri, 2011).

Menurut Biddle \& Thomas dalam Sarwono (2015 : 215) teori peran dibagi dalam empat golongan yaitu :

1. Orang-orang yang mengambil bagian dalam interaksi sosial;

2. Perilaku yang muncul dalam interaksi tersebut;

3. Kedudukan orang-orang dalam berperilaku;

4. Kaitan antar orang dan perilaku.

Biddle dan Thomas dalam Sarwono (2015:224), menyatakan bahwa peran adalah serangkaian rumusan yang membatasi perilaku-perilaku yang diharapkan dari pemegang kedudukan tertentu. Hal ini senada dengan Suhardono (1994:15), mendefinisikan bahwa peran merupakan seperangkat patokan, yang membatasi apa perilaku yang mesti dilakukan oleh seseorang, yang menduduki suatu posisi. Sedangkan menururt Soekanto (2007: 213), peran adalah aspek dinamis kedudukan (status), apabila seseorang 
melaksanakan hak dan kewajibannya sesuai dengan kedudukannya, maka ia menjalankan suatu peranan.

\section{Definisi Strategi}

Strategi adalah alat untuk mencapai tujuan, dalam pengembangannya konsep mengenai strategi harus terus memiliki perkembangan dan setiap orang mempunyai pendapat atau definisi yang berbeda mengenai strategi. Menurut Rangkuti (2013 : 183) berpendapat bahwa strategi adalah perencanaan induk yang komprehensif, yang menjelaskan bagaimana perusahaan akan mencapai semua tujuan yang telah ditetapkan berdasarkan misi yang telah ditetapkan sebelumnya.

Menurut Hamel \& Prahalad dalam buku Rangkuti (2009:4), Strategi merupakan tindakan yang bersifat incremental (senantiasa meningkat) dan terus-menerus dilakukan berdasarkan sudut pandang tentang apa yang diharapkan oleh para pelanggan di masa depan. Dengan demikian perencanaan strategi hampir selalu dimulai dari "apa yang dapat terjadi", bukan dimulai dari "apa yang terjadi". Terjadinya kecepatan inovasi pasar baru dan perubahan pola konsumen memerlukan kompetensi inti (core competencies). Perusahaan perlu mencari kompetensi inti di dalam bisnis yang dilakukan. Sedangkan menurut Porter dalam buku Rangkuti (2009:4), strategi adalah alat yang sangat penting untuk mencapai keunggulan bersaing.

\section{Definisi Desa Wisata}

Menurut Peraturan Kementerian Kebudayaan dan Pariwisata No 18 tahun 2011, Desa wisata merupakan suatu bentuk integrasi antara atraksi, akomodasi, dan fasilitas pendukung yang disajikan dalam suatu struktur kehidupan masyarakat yang menyatu dengan tata cara dan tradisi yang berlaku. Suatu desa wisata memiliki daya tarik yang khas (dapat berupa keunikan fisik lingkungan alam perdesaan, maupun kehidupan sosial budaya masyarakatnya) yang dikemas secara alami dan menarik sehingga daya tarik perdesaan dapat menggerakkan kunjungan wisatawan ke desa tersebut.

Masyarakat menjadikan rumah-rumah mereka atau sebagian kamar-kamar mereka menjadi tempat tinggal tamu sementara (homestay) dalam suatu desa wisata. Akan menjadi komplit apabila tamu-tamu bisa menikmati keseharian rakyat (live in) merasakan sajian makan dan jenis atraksi kebudayaan desa. Desa wisata akan sukses kalau seluruh anggota masyarakat baik kepala keluarga, ibu-ibu rumah tangga, pemuda, dan anak-anak ikut mendukung keberadaan desa wisata tersebut (Hasbullah, 2010).

\section{Definisi Keunggulan Bersaing}

Menurut Freddy Rangkuti (2014), keunggulan bersaing adalah strategi bersaing terhadap sesuatu yang dirancang untuk dieksplotasi oleh suatu organisasi, keunggulan bersaing yang dimaksudkan disini yaitu kegiatan spesifik yang dikembangkan oleh perusahaan agar lebih unggul dibandingkan dengan pesaingnya. Keberhasilan suatu strategi yang telah ditetapkan sangat ditentukan oleh seberapa besar tingkat kesesuaian strategi tersebut dengan perubahan lingkungan, pesaing, serta situasi organisasi.

Amstrong dan Kotler (2005:211) mendefinisikan keunggulan bersaing sebagai keunggulan diatas pesaing yang diperoleh dengan menawarkan nilai kepada konsumen, baik melalui harga yang lebih rendah atau dengan menyediakan lebih banyak manfaat yang mendukung pendapatan. Sedangkan Barney (1991) menyatakan definisi keunggulan bersaing adalah ketika dua perusahaan bersaing (pada pasar dan pelanggan yang sama), satu perusahaan memiliki tingkat keuntungan dan potensi mendapatkan laba yang lebih tinggi daripada perusahaan lainnya.

Beberapa indikator yang digunakan untuk mengukur keunggulan bersaing adalah keunikan, jarang dijumpai, tidak mudah ditiru dan harga bersaing. Keunikan produk adalah keunikan produk perusahaan yang memadukan nilai seni dengan selera pelanggan. Harga bersaing adalah kemampuan perusahaan untuk menyesuaikan harga produknya dengan harga umum di pasaran. Tidak mudah dijumpai berarti 
keberadaannya langka dalam persaingan yang saat ini dilakukan. Tidak mudah ditiru berarti tidak dapat ditiru dengan sempurna.

\section{Revolusi Industri 4.0}

Sejarah globalisasi menunjukkan bahwa setiap perubahan zaman memiliki core (penggeraknya) masing-masing. Uraian Friedman, Ritzer, dan Toffler menunjukkan bahwa gerak perubahan itu selalu dipicu oleh perkembangan teknologi yang melahirkan era revolusi industri 4.0, yang tidak hanya sekedar membuka interaksi secara luas namun juga mendisrupsi berbagai bidang kehidupan manusia.

Disruptif pada awalnya merupakan fenomena yang terjadi dalam dunia ekonomi, khususnya di bidang bisnis. Clayton (Christensen, 1997), seorang Profesor Bisnis Harvard menyebutnya sebagai distruption innovative dalam The Innovator's Dilemma (Christensen, 1997). Disruptif sendiri merupakan kondisi ketika sebuah bisnis dituntut untuk terus berinovasi mengikuti perkembangan, sehingga bisnis tidak hanya untuk memenuhi kebutuhan-kebutuhan sekarang, namun dapat mengantisipasi kebutuhan di masa mendatang.

Di era sekarang, disrupsi tidak hanya berlaku pada dunia bisnis. Fenomena disrupsi memberikan dampak perubahan yang besar dalam berbagai bidang. Disrupsi tidak hanya mengubah bisnis, tapi fundamental bisnisnya (Khasali, 2018). Mulai dari struktur biaya sampai ke budaya, dan bahkan ideologi dari sebuah industri.

Paradigma bisnis pun bergeser dari penekanan owning menjadi sharing (kolaborasi). Contoh nyata dapat dilihat pada perpindahan bisnis retail (toko fisik) ke dalam e-commerce yang menawarkan kemudahan dalam berbelanja, ditambah merebaknya taksi online kemudian mengancam eksistensi bisnis taksi konvensional.

\section{METODE PENELITIAN}

Penelitian ini dilakukan di Desa Blimbingsari. Lokasi yang diambil dalam penelitian ini ditentukan dengan sengaja (purposive), yang dilakukan di Desa Wisata Blimbingsari yaitu Desa Wisata Rohani yang terletak di Kecamatan Melaya, Kabupaten Jembrana, Propinsi Bali. Penelitian ini merupakan sebuah penelitian dengan metode kualitatif deskriptif. Bogdan dan Taylor dalam Moleong (2007:4) mendefinisikan penelitian kualitatif sebagai prosedur penelitian yang menghasilkan data deskriptif berupa kata-kata tertulis atau lisan dari orang-orang dan perilaku yang diamati dari fenomena yang terjadi. Teknik pengumpulan data yang digunakan dalam penelitian ini adalah :

\section{Teknik wawancara mendalam (in-depth interview).}

Wawancara merupakan percakapan dengan maksud tertentu, yang dilakukan oleh dua pihak. Menurut Moleong (2007:186) wawancara mendalam merupakan proses menggali informasi secara mendalam, terbuka, dan bebas dengan masalah dan fokus penelitian dan diarahkan pada pusat penelitian. Wawancara mendalam digunakan untuk memperoleh keterangan secara detail dan spesifik dari informan yang terlibat langsung dengan apa yang sedang diteliti. Penggalian informasi dilakukan untuk mengetahui pendapat mereka berdasarkan perspektif responden dalam memandang sebuah permasalahan. Teknik wawancara ini dilakukan oleh seorang pewawancara dengan mewawancarai satu orang secara tatap muka (face to face).

\section{Dokumentasi}

Dokumen merupakan catatan peristiwa yang sudah berlalu. Dokumen bisa berbentuk tulisan, gambar, atau karya-karya monumental seseorang Sugiono (2016:213). 
Dalam penelitian ini, dokumentasi diperlukan sebagai bukti melakukan wawancara terhadap informan. Dokumen merupakan catatan peristiwa yang sedang terjadi atau bahkan sudah berlalu bisa berbentuk penelitian terdahulu atau bahkan dapat berupa jejak digital.

Dalam penelitian ini, informan ditentukan dengan teknik purposive sampling yaitu teknik pengambilan sampel sumber data yang didasarkan dengan pertimbangan tertentu. Pertimbangan tertentu ini adalah orang yang dianggap paling tahu tentang apa yang akan peneliti harapkan, atau sebagai penguasa sehingga memudahkan peneliti menjelajahi objek/situasi sosial yang diteliti. Dalam penelitian ini, informan yang mengetahui secara detail terkait masalah yang akan dibahas pada latar belakang yaitu :Kepala Desa/Prebekel; Sekretaris Desa; Bendahara BUMDes; Ketua/Sekretaris Komite Pariwisata; Pengelola Obyek Wisata/Pemilik Homestay; Tokoh Masyarakat; dan Akademisi.

\section{HASIL PENELITIAN DAN PEMBAHASAN}

Desa Blimbingsari merupakan salah satu desa di Bali Barat. Desa Blimbingsari mempunyai keunikan tersendiri karena semua penduduk $100 \%$ memeluk agama Kristen Protestan dan merupakan orang Bali asli dimana orang Bali pada umumnya memeluk agama Hindu.

Desa Blimbingsari berawal dari tahun 1939, saat itu, para Tetua datang dari Kabupaten Badung dan sekitarnya untuk mencari lokasi untuk bertransmigrasi. Dulunya Desa Blimbingsari merupakan hutan lebat yang disebut Alas Angker, banyak binatang buas dan penyakit mematikan (malaria) dan diyakini tidak mungkin ada kehidupan manusia di alas tersebut. Setelah survey dan mendapat izin dari Pemerintah Kolonial Belanda pada waktu itu, akhirnya Desa Blimbingsari mulai dibangun.

Keunikan lain dari desa Blimbingsari yaitu mengenai arsitektur bangunan Gereja yang dibuat masih menggunakan struktur yang sama dengan bangunan pura di Bali. Awalnya, gereja di Desa Blimbingsari dibangun dengan gaya arsitektur Eropa, namun pada tahun 1971 gereja rusak akibat gempa bumi. Gereja kemudian dibangun ulang dengan menggunakan struktur yang sama dengan bangunan pura di Bali yakni ada halaman luar atau jaba sisi, ada bangunan gapura atau candi bentar, dan tempat sembahyang atau bale pesamuan. Bangunan gereja untuk sembahyang dibuat terbuka seperti bangunan pura di Bali, yaitu tanpa tembok penyekat.

Mengenai tata cara ibadah atau sembahyang, Gereja di Blimbingsari menggunakan tata ibadah konstektual pada minggu 1 (satu) setiap bulannya. Warga mengenakan pakaian adat Bali madya, menggunakan bahasa Bali, dan gamelan Bali. Pada hari raya seperti Natal, Paskah, Pentakosta dan hari raya besar umat Nasrani lainnya masih menggunakan budaya memenjor (membuat penjor) dan membuat makanan khas Bali seperti aneka lawar menjelang hari Raya Natal. Budaya menggunakan kentongan seperti pada masyarakat Hindu Bali pada umumnya juga masih digunakan, menggunakan kentongan untuk pelaksanaan ibadah, kegiatan warga, pemberitahuan ada kematian warga dan juga apabila ada musibah.

Berdasarkan wawancara dengan informan Sekretaris Komite Pariwisata Desa Blimbingsari (Murtiyasa, 2020), Desa Wisata Blimbingsari pernah mendapatkan penghargaan diantaranya yaitu Juara 1 Kategori Sylver Desa Wisata Berbasis Masyarakat dari CSR Bank Indonesia pada tahun 2012, Predikat Desa Terbersih di Kabupaten Jembrana pada Tahun 2017, juara pertama ISTA (Indonesian Sustainable Tourism Award) kategori Community Based Tourism Village yang diselenggarakan oleh Kementerian Pariwisata Republik Indonesia pada tahun 2017 dan Penghargaan dari IAI (Ikatan Arsitektur Indonesia) Bali Award kepada Gereja dan Warga Gereja GKPB Pniel Blimbingsari sebagai rumah ibadah (Gereja) beraksitektur Bali.

Berdasarkan wawancara dengan Bapak I Made John Ronny dalam kapasitasnya sebagai Perbekel tentang Peran dan Strategi desa wisata dalam membangun keunggulan bersaing di Era Revolusi Industri 4.0, Dalam wawancara Bapak I Made John Ronny sebagai Perbekel Desa Blimbingsari menyatakan bahwa " 
..Berbicara mengenai peran dan strategi Pemerintah Desa, terutama dalam digitalisasi, kami selaku Perbekel terpilih dalam 2 periode dan saat ini melanjutkan dalam periode ke 3 tahun 2020-2026, tentu melihat dari berbagai sisi. Sisi pertama Desa Blimbingsari yang merupakan Desa Wisata Rohani Kristen dan satu-satunya di Bali yang 100\% penduduknya beragam Kristen dan masih memegang teguh budaya dan adat istiadat Bali, ini merupakan keunikan kami sebagai Desa Wisata. Keunikan dan keotentikan Desa Blimbingsari ini menjadi kekuatan kami selain agrowisata. Sesuai dengan misi kami periode 2020-2026, dengan keunikan yang kami miliki, kami akan meningkatkan sektor-sektor yang akan menjadi prioritas kami dalam pengembangan Desa Wisata. Inovasi-inovasi bekerjasama dengan pihak-pihak yang terkait tentu kami lakukan. Kami bersyukur tahun 2017 kami meraih penghargaan ISTA (Indonesian Sustainable Tourism Award) kategori Community Based Tourism Village yang diselenggarakan oleh Kementerian Pariwisata Republik Indonesia sehingga segala sesuatunya menjadi semakin dipermudah dalam mencari kolega untuk berkolaborasi. Pemerintah Kabupaten Jembrana juga mengapresiasi dan sangat mendukung kegiatan pariwisata di Desa Blimbingsari, bahkan kami dijadikan sebagai desa contoh untuk melakukan studi banding desa lain di Kabupaten Jembrana...............Kekuatan Desa Blimbingsari ada pada peguyuban/diasporanya, maksudnya masyarakat Desa Blimbingsari yang asalnya dari Blimbingsari tetapi sudah berdomisili atau menetap di luar daerah maupun luar negeri. Meraka yang selalu memberikan promosi melalui mulut ke mulut mengenai keindahan maupun keotentikan dan keunikan Desa Blimbingsari kepada orang lain sehingga menjadikan keinginan untuk mengunjungi Desa Wisata Blimbingsari, tetapi kekuatan media sosial saat ini juga menjadi sangat penting pada saat/situasi yang serba digital maupun tidak menentu saat ini.............. Desa Blimbingsari sudah memiliki Pokdarwis (Kelompok Sadar Wisata) yang dilaksanakan oleh volunteer yang disebut Komite Pariwisata Blimbingsari tetapi pada tahun 2018, Komite Pariwisata Blimbingsari dimasukkan menjadi unit usaha Badan Usaha Milik Desa (BUMDes) agar supaya bisa terorganisir dengan baik terutama mengenai keuangannya. Di bawah pengelolaan BUMDes, Komite Pariwisata Blimbingsari akan bergerak dengan lebih baik, akuntabel dan kelemahan selama ini dalam bidang SDM tentu akan menjadi prioritas untuk ditingkatkan.............Pemerintah Desa Blimbingsari belum memiliki SDM yang mampu mendukung pelayanan prima dalam penguasaan teknologi informasi dan digitalisasi dalam pariwisata, oleh sebab itu pemerintah desa melalukan kolaborasi dalam teknis maupun peningkatan kualitas SDM dengan berbagai pihak, salah satunya dengan BPD Bali dalam hal bantuan dan juga digitalisasi desa berbasis QRIS (Quick Respon Code Indonesian Standart) yang diresmikan pada tanggal 22 Juli 2020 oleh Bapak Wakil Gubernur Bali Tjokorda Oka Artha Ardana Sukawati (Cok Ace), dan Bupati Jembrana, I Putu Artha, bertransaksi melalui aplikasi digital terutama mengenai pembayaran homestay/penginapan dan juga Food and Beverage pada UMKM di Desa Blimbingsari.

\section{Kaitan Peran Pemerintah Desa wisata Blimbingsari dan perilaku dalam membangun keunggulan bersaing.}

\section{Pemerintah Desa Wisata Blimbingsari menjadi stabilitator.}

Pemerintah Desa Blimbingsari menjadi stabilitator dalam pengembangan dan penerapan strategi untuk membangun keunggulan bersaing sebagai desa wisata. Hal ini dapat dilihat dari perumusan dan pembuatan program-program yang memprioritaskan dan sesuai dengan kebutuhan dan juga potensi dari Sumber Daya Manusia, Sumber Daya Alam dan masyarakat Desa Wisata Blimbingsari.

Dalam Perkembangannya, Pemerintah Desa Wisata Blimbingsari merubah pengelolaan Komite Pariwisata Desa Blimbingsari yang sebelumnya langsung bertanggung jawab kepada Perbekel/Kepala Desa, pada tahun 2018, pengelolaan Komite Pariwisata Desa Blimbingsari menjadi unit bisnis dari Badan Usaha Milik Desa (BUMDes) Desa Blimbingsari. Komite Pariwisata Desa Blimbingsari sendiri diresmikan oleh 
Dinas Pariwisata dan Kebudayaan Pemerintah Kabupaten Jembrana dengan Surat Keputusan Kepala Dinas Pariwisata dan Kebudayaan (SKKDPK) Kabupaten Jembrana No. 19/PR/DISPARBUD/2017 tentang Pengukuhan Susunan Personalia Pengelola Pariwisata dan Kelompok Sadar Wisata Desa Blimbingsari.

Pembentukan Komite Pariwisata dimaksudkan agar masyarakat sadar akan pengelolaan wisata di Desa Blimbingsari. Dengan melakukan kerjasama pemerintah desa dan masyarakat akan lebih mudah dalam percepatan pembangunan dan pengembangan serta pengintegrasian pengelolaan wisata rohani Desa Blimbingsari. Dengan adanya Komite Pariwisata, berperan membantu dalam mempromosikan Desa Wisata Rohani Blimbingsari, hal ini karena Komite Pariwisata merupakan fasilitator antara wisatawan yang berkunjung dengan masyarakat yang mengelola destinasi wisata serta pemilik homestay yang merupakan tujuan wisata.

Sebagai Stabilitator, Pemerintah Desa Blimbingsari menyampaikan kebijakan serta program-program mengenai desa wisata kepada masyarakat Desa Wisata Blimbingsari. Penyampaian dengan cara sosialisasi program-program , rapat koordinasi, serta bimbingan teknis kepada masyarakat dan perangkat-perangkat desa. Pemerintah Desa memberikan sosialisasi mengenai program-program yang akan dilaksanakan biasanya setahun 1 kali, pada tingkat Dusun Pemerintah Desa mengadakan koordinasi/rapat yang dinamakan Musyawarah Dusun (MUSDUS) yang diadakan pada setiap bulan April. Pada tingkat Desa diadakan Musyawarah Desa (MUSDES) yang diadakan pada bulan Mei dan Musyawarah Rencana Pengembangan Desa (MUSRENBANGDES) pada bulan September yang pelaksanaannya diikuti oleh Perbekel, Tokoh Masyarakat, Pendeta, Ketua BPD, LPM, Perangkat Desa dan Camat. Pemerintah Desa juga memfasilitasi aspirasi dari setiap warga masyarakat Desa Wisata Blimbingsari dalam program pembangunan dan pengembangan dan juga pemberdayaan masyarakat.

Sosialisasi perlu dilakukan oleh Pemerintah Desa Blimbingsari agar supaya pemahaman masyarakat desa mengenai pembangunan dan pengembangan potensi wisata dapat dipahami dengan baik. Setelah sosialisasi dilaksanakan, diharapkan masyarakat Desa Blimbingsari mengetahui mengenai potensi wisata di Desa Wisata Blimbingsari dan masyarakat bisa berperan aktif dalam pengelolaan untuk meningkatkan perekonomian masyarakat sehingga kesejahteraan masyarakat bisa ditingkatkan.

\section{Pemerintah Desa Wisata Blimbingsari menjadi inovator.}

Desa Wisata Blimbingsari merupakan desa yang unik. Selain menjadi pusat wisata rohani agama Kristen di Bali, Desa Wisata Blimbingsari juga memiliki potensi wisata lain yang layak untuk dikembangkan sebagai pendukung wisata rohani. Potensi wisata tersebut harus dikelola dengan baik agar dapat menjadi berkembang selaras dengan wisata rohani di Desa Blimbingsari, untuk itulah peran pemerintah desa dalam melakukan inivasi-inovasi dalam pengembangan potensi desa diperlukan. Peran Pemerintah sebagai inovator.

Dari penelitian, observasi dan dokumentasi oleh peneliti, inovasi dalam pengembangan potensi wisata yang dilakukan Pemerintah Desa Blimbingsari dan sebagai destinasi lain selain wisata rohani antara lain adalah pengelolaan wisata alam/Eco Tourism dengan Jungle Tracking Advenure \& Birdwatching Photography, pengelolaan wisata seni dan budaya/art and culture tourism dengan kesenian megambel, menari serta kesenian memenjor yang masih dilakukan dalam memperingati hari-hari raya besar agama Kristen seperti Natal, Paskah dan Pentakosta. Pengelolaan dan pengembangan wisata pertanian/Agro Tourism dengan usaha perkebunan coklat dan kelapa yang bisa dijadikan destinasi wisata dan melibatkan wisatawan dalam aktivitas pertanian. Wisata dengan Spot Selfie yang kekinian dan Instagrammable, dengan keunikan arsitektur gedung gereja dan juga adanya spot-spot selfie buatan menjadikan Desa Wisata Blimbingsari menjadi unik untuk wisata berfoto. Pengelolaan dan pengembangan objek wisata hiburan dan rekreasi dengan Family Park "Nyiur Melambai" yaitu destinasi wisata wahana bermain air menjadikan destinasi ini menjadi pendukung wisata rohani di Desa Wisata Blimbingsari. 
Perkembangan teknologi informasi memaksa Pemerintah Desa Blimbingsari untuk melakukan inovasi dan kolaborasi. Pemerintah Desa terus berbenah dan meningkatkan diri dalam digitalisasi desa. Pemerintah Desa menyadari bahwa diperlukan kesiapan investasi dan kesiapan sumber daya manusia dalam pengembangan teknologi informasi agar bisa membangun keunggulan bersaing, oleh karena itu Pemerintah Desa Wisata Blimbingsari melakukan pembenahan sesuai dengan tuntutan persaingan saat ini. Salah satu inovasi yang dilakukan oleh Pemerintah Desa Wisata Blimbingsari adalah digitalisasi desa berbasis QRIS (Quick Respon Code Indonesian Standard) yang berkolaborasi dengan Bank Indonesia (BI) dan Bank Pembangunan Daerah (BPD) Bali. Penetapan Desa Wisata Blimbingsari sebagai desa wisata berbasis QRIS diresmikan oleh Bapak Wakil Gubernur Bali Tjokorda Oka Artha Ardana Sukawati (Cok Ace) dan Bupati Jembrana, I Putu Artha pada tanggal 22 Juli 2020. Tujuan dari digitalisasi desa berbasis QRIS (Quick Respon Code Indonesian Standard) yaitu mempermudah proses transaksi pembayaran homestay dan juga food and beverage pada UMKM di Desa Blimbingsari dengan menggunakan QR Code QRIS sehingga aplikasi QR Code yang banyak bisa di aplikasikan dengan hanya satu QRIS.

Kolaborasi dan inovasi juga dilakukan dengan Perguruan Tinggi Swasta dan Negeri yang ada di Bali maupun di luar Bali. Salah satunya dengan Perguruan Tinggi Swasta yang ada di Kabupaten Badung yaitu Universitas Dhyana Pura Bali. Dengan media digital, promosi Desa Wisata Blimbingsari menjadi lebih mudah dan bisa menyasar ke berbagai elemen dan golongan. Universitas Dhyana Pura melalui program Pengabdian Kepada Masyarakat membantu Pemerintah Desa Blimbingsari membuat Website serta pelatihan dalam mengisi konten-konten wisata maupun destinasi wisata yang menarik mengenai Desa Wisata Blimbingsari. Pelatihan dalam pengelolaan homestay dan juga pelatihan dalam manajemen food and beverage.

Pemerintah Desa Wisata Blimbingsari juga mendapatkan kesempatan berkolaborasi, melakukan sosialisasi kepada masyarakat desa dan inovasi dalam digitalisasi homestay dengan Sekolah Tinggi Pariwisata (STP) Nusa Dua Bali. Tim dari STP Nusa Dua Bali melakukan pelatihan kepada pemilik homestay dalam hal mempromosikan wisata melalui media sosial seperti facebook, Instagram, twitter dan melalui blog. Dalam hal ini Pemerintah Desa menjadi fasilitator dalam berkolaborasi dan inovator dalam pengembangan Sumber Daya Manusia.

\section{Pemerintah Desa Wisata Blimbingsari menjadi motivator.}

Dari hasil penelitian, observasi dan wawancara yang telah peneliti lakukan, di dalam menjalankan tugasnya melaksanakan program-program Desa Wisata, Pemerintah Desa Blimbingsari masih menemui kendala-kendala dalam melaksanakan pembangunan dan pengembangan desa wisata. Secara demografis tingkat pendidikan masyarakat Desa Blimbingsari yang sebagian besar menengah atas menjadikan upayaupaya pemerintah dalam melakukan pelatihan dan sosialisasi tentang pariwisata menjadi lebih berat. Pemahaman yang tidak sama tentang pariwisata, adanya kemampuan pola pikir masyarakat yang masih tradisional, dan kurangnya kesadaran masyarakat dalam mengembangkan desa wisata menjadikan pemerintah belum masksimal dalam menjalankan fungsinya.

Dalam upaya untuk memotivasi dalam memberdayakan masyarakat desa wisata Blimbingsari agar masyarakat lebih berperan serta dalam membangun daya saing desa wisata, pemerintah desa melakukan upaya-upaya dan bekerja sama dengan pemerintah dan swasta dalam memberikan motivasi. Tim dari Taman Nasional Bali Barat memberikan motivasi kepada masyarakat untuk ikut ambil bagian dalam penangkaran dan pengembangbiakan satwa endemik Bali Barat yaitu burung Jalak Bali, hal ini bertujuan agar masyarakat lebih peduli kepada satwa langka dan nantinya bisa menjadi potensi wisata baru yaitu wisata penangkaran burung Jalak Bali sebagai pendukung wisata rohani di Desa Wisata Blimbingsari.

Pemerintah juga mendatangkan motivator baik dari Perguruan tinggi Negeri maupun swasta untuk memberikan motivasi, pengetahuan, pendidikan dan pelatihan kepada pemilik homestay dalam upaya memberikan pelayanan maksimal kepada wisatawan yang menginap. Hal ini di dorong dengan maksud 
untuk mengembangkan Sumber Daya Manusia yang berdaya saing tinggi, berkualitas dan berintegritas, bermutu, profesional dan bermoral serta memiliki jati diri yang kokoh yang dikembangkan berdasarkan kearifan lokal masyarakat Desa Blimbingsari.

Dalam upaya untuk mengembangkan potensi Desa Wisata Blimbingsari menjadi lebih baik, Pemerintah Daerah Bali dan Pemerintah Kabupaten Jembrana melalui Dinas Pariwisata dan Kebudayaan dan lebih banyak melalui Forum Komunikasi Desa Wisata (Forkomdewi), memberikan motivasi, pendidikan dan pelatihan kepada masyarakat DEsa Wisata Blimbingsari seperti pelatihan housekeeping (pelatihan pengelolaan kamar dan layanan kamar), dan pelatihan food and beverage (pelatihan membuat makanan dan minuman)/breakfast yang nanti dinikmati oleh wisatawan.

Pemerintah Desa wisata memberikan pendidikan dan latihan kepada untuk memotivasi Komite Pariwisata untuk mengadakan studi banding ke desa wisata lain untuk menambah pengetahuan dan pengelolaan dalam hal promosi desa wisata kemudian dapat mereplikasi strateginya jika hal itu sesuai dengan situasi dan kondisi Desa Wisata Blimbingsari.

\section{Tantangan dan hambatan Pemerintah Desa dalam membuat strategi dalam membangun keunggulan bersaing.}

Dalam menjalankan peran dan strategi tentu ada tantangan dari internal maupun dari eksternal yang mempengaruhi pemerintah desa wisata Blimbingsari dalam menentukan strategi dalam membangun keunggulan bersaing. Inovasi-inovasi yang dilakukan dengan mendigitalisasi desa wisata berbasis QRIS tentu harus didukung dengan peningkatan kualitas Sumber Daya Manusia yang harus bisa menguasai teknologi informasi dan ini membuat peran pemerintah desa Blimbingsari sangat penting dalam mempersiapkan semuanya itu agar bisa bersaing di era digital seperti saat ini.

Pemerintah Desa Blimbingsari telah berkolaborasi dengan Bank Indonesia (BI) dan Bank Pembangunan Daerah (BPD) Bali dalam digitalisasi Desa Wisata Blimbingsari berbasis QRIS tetapi dalam penerapannya masyarakat pemilik homestay dan UMKM belum secara maksimal bisa menggunakannya. Keterbatasan sarana internet menjadi salah satu faktor yang menghambat penerapan digitalisasi desa dalam melakukan transaksi pembayaran menggunakan QRIS terutama dalam pembayaran homestay.

Kemampuan masyarakat yang berbeda-beda menyebabkan digitalisasi desa berbasis QRIS juga belum maksimal. Masyarakat lebih senang mendapatkan pembayaran atau bertransaksi secara tunai karena menganggap lebih praktis. Hal ini dikarenakan keterbatasan adanya Anjungan Tunai Mandiri (ATM) dari bank terkait yang sama sekali belum ada di Desa Wisata sehingga menyulitkan pemilik homestay dan juga masyarakat untuk mendapatkan dana tunai.

Dalam pemerintahan 2020-2026, Pemerintah Desa Blimbingsari mempunyai tantangan dalam pembangunan saran dan prasarana penunjang berwisata. Belum tersedianya toilet umum dan juga tempat pembuangan akhir sampah menjadi tantangan ke depan untuk melengkapi sarana dan prasana pendukung pariwisata.

\section{SIMPULAN}

Berdasarkan penelitian yang dilakukan peneliti yang berjudul Menguji Strategi Desa Wisata dalam Membangun Keunggulan Bersaing di Era Revolusi Industri 4.0, dapat ditarik kesimpulan untuk menjawab rumusan masalah-masalah adalah sebagai berikut.

1. Pemerintah Desa Blimbingsari di dalam melakukan dan menjalankan strategi desa wisata dalam membangun Keunggulan Bersaing di Era Revolusi Industri 4.0 sudah dilakukan dengan bertahap. Dimulai dengan melakukan menjadikan Komite Pariwisata Desa Blimbingsari sebagai unit bisnis Badan Usaha Milik Desa (BUMDes) sehingga kegiatan-kegiatan pariwisata Desa Wisata Blimbingsari bisa dilaksanakan dengan profesional. 
2. Penetapan Digitalisasi Desa Wisata Blimbingsari sebagai Desa Wisata berbasis QRIS (Quick Respon Code Indonesian Standard) dengan bekerja sama dan berkolaborasi dengan Bank Indonesia (BI) dan Bank Pembangunan Daerah (BPD) Bali. Dengan adanya QRIS mempermudah proses transaksi pembayaran homestay dan juga food and beverage pada UMKM di Desa Blimbingsari, dengan menggunakan $Q R$ Code QRIS sehingga aplikasi QR Code yang banyak bisa di aplikasikan dengan hanya satu QRIS.

3. Peningkatan Kualitas Sumber Daya Manusia menjadi hal yang penting dan perlu menjadi perhatian dari Pemerintah Desa Wisata Blimbingsari. Dengan adanya digitalisasi desa berbasis QRIS seharusnya mempermudah dalam pelayana pembayaran dan transaksi homestay, tetapi karena kualitas sumber daya manusia yang masih rendah mengakibatkan digitalisasi desa berbasis QRIS belum terlalu maksimal.

4. Desa Wisata Blimbingsari yang merupakan desa wisata rohani yang mempunyai keunikan dan keotentikan sebagai satu-satunya Desa wisata rohani Kristen di Bali dan $100 \%$ penduduknya beragama Nasrani ternyata menyimpan potensi wisata yang lain. Secara geografis, letak Desa Wisata Bimbingsari yang berada pada wilayah Taman Nasional Bali Barat (TNBB) di sebelah utara menjadikan Blimbingsari mempunyai satwa endemic yaitu burung Jalak Bali yang langka dan mulai dikembangbiakan dalam penangkaran oleh masyarakat Blimbingsari. Memiliki Hutan Taman Nasional Bali Barat di sebelah utara menjadikan potensi wisata echo tourism dapat dikembangkan. Potensi wisata jungle tracking adventures dan birdwatching and photography menjadi potensi wisata yang menarik bagi wisatawan yang suka berpetualang. Potensi wisata agro tourism juga menjadi wisata yang menarik untuk dikembangkan karena wilayah Desa Wisata Blimbingsari yang memiliki perkebunan kelapa dan kakao menajdi menarik bagi wisatawan yang ingin beragrowisata. Dengan potensi yang dimiliki, gedung gereja yang mendapatkan penghargaan dari Ikatan Arsitektur Indonesia (IAI), gedung gereja Desa Blimbingsari juga menjadi potensi wisata kekinian/instagammable baik dalam ber-selfie maupun untuk pre-wedding.

5. Adanya faktor-faktor penghambat dan juga tantangan yang perlu dihadapi dan dibenahi oleh pemerintah desa Blimbingsari dalam membangun keunggulan bersaing di era revolusi industry 4.0, baik dari internal maupun dari eksternal yang harus diatasi.

\section{DAFTAR PUSTAKA}

Alas, R., Übius, U., Lorents, P., \& Matsak, E. (2017). Corporate Social Responsibility In European And Asian Countries. Jurnal Manajemen Bisnis Dan Inovasi (JMBI) UNSRAT Vol. 4 No. 1

Agus Muriawan Putra, 2006. Konsep Desa Wisata. Jurnal Manajemen Pariwisata, Juni 2006, Volume 5, Nomor 1. Dosen D4 Pariwisata Universitas Udayana.

Apriani dan Atong, (2020). Peran Pemerintah Desa dalam Pengembangan Ekowisata Danau Jemelak. Societas, p-ISSN: 2252-603X, e-ISSN: 2354-7693.

Bifadhoilah, Dipta dan Ahra. (2020). Peran dan Strategi Pemerintah Daerah dalam pengelolaan ruang terbuka hijau (RTH) di Kota Batu. Prosiding Simposium Nasional. (ISBN 978-602-73470-5-2.

David, Fred, R. (2011). Strategic Management, Manajemen Strategi Konsep, Edisi 12. Jakarta. Salemba Empat.

Hunger, J. David dan Wheelan, Thomas L. Manajemen Strategis. Yogyakarta. Andi. 
Karamoy, H., \& Tulung, J. E. (2020). The Effect of Banking Risk on Indonesian Regional Development Bank. Banks and Bank Systems, 15(2), 130-137

Karamoy, H., \& Tulung, J. E. (2020). The Effect of Financial Performance And Corporate Governance To Stock Price In Non-Bank Financial Industry. Corporate Ownership \& Control, 17(2), 97-103

Khasali, R. (2018). Disruption. Jakarta. Gramedia Pustaka Utama.

Maryanti, Wiwik. (2018). Peran UKM dalam memposisikan produk khas daerah melalui manajemen image di Era persaingan Global. Jurnal Bisma SINTA 2. Unesa. ISSN 2549-7790 (online) ISSN 1979-7192 (print).

Pendataan Potensi Desa (Podes) 2018 No. 06/01/51 Th. II, 2 Januari 2019 dari Badan Pusat Statistik Provinsi Bali.

Moleong, Lexy J. 2007. Metodologi Penelitian Kualitatif. Bandung. PT. Remaja Rosdakarya Offset.

Rangkuti, Freddy, (2014). Analisis SWOT : Teknik Membedah Kasus Bisnis. Jakarta. Gramedia Pustaka Utama

Saputra, Agus Jaya dan Maradona, Agus Fredy. Explorasi Masyarakat Lokal dalam Pengembangan Desa Wisata. IHDN.

Sari, Sintiya Marcela (2017) Peran Pemerintah Dalam Meningkatkan Keunggulan Kompetitif Pengrajin Tenun Ikat Bandar Kidul (Studi pada Desa Bandar Kidul, Kota Kediri). Sarjana thesis, Universitas Brawijaya.

Sugiyono, (2016). Metode Penelitian Kuantitatif, Kualitatif dan R\&D. Bandung. PT. Alfabet. Danandjadja, James. (1984). Folklor Indonesia.

Suswantoro, 2007. Dasar-Dasar Ilmu Pariwisata, Penerbit CV. Andi Offset, Yogyakarta.

Tulung, J. E., \& Ramdani, D. (2018). Independence, size and performance of the board: An emerging market research. Corporate Ownership \& Control, 15(2-1), 201-208.

Undang-Undang Republik Indonesia Nomor 10 Tahun 2009 Tentang Kepariwisataan.

Undang-Undang Republik Indonesia Nomor 6 Tahun 2015 tentang Desa (UU Desa)

Undang-undang nomor 22 Tahun 1999 tentang Pemerintahan Daerah. 